\title{
Identifikasi Pengaruh Proses Perebusan dan Penggorengan Kacang Tolo (Vigna unguiculata L. Walp.) terhadap
} Komposisi Fitosterol

Noor Erma Nasution Sugijanto ${ }^{1}$, Citra Hayu Adi Makayasa $^{2}$, Gita Deseria ${ }^{1}$, Rahmania Alrika Ilma Bridgeta ${ }^{1}$, Miftakhul Rohmah Putri ${ }^{1}$, Catur Dian Setiawan ${ }^{3}$, Sugijanto ${ }^{1}$

${ }^{1}$ Departemen Kimia Farmasi, Fakultas Farmasi, Universitas Airlangga, Surabaya, Indonesia

${ }^{2}$ Magister Ilmu Farmasi, Fakultas Farmasi, Universitas Airlangga, Surabaya, Indonesia

${ }^{3}$ Departemen Farmasi Komunitas, Fakultas Farmasi, Universitas Airlangga, Surabaya, Indonesia

*Corresponding author: noor-e-n@ ff.unair.ac.id

Submitted: 10 Januari 2020

Accepted: 10 Februari 2020

Published: 25 Juni 2020

\begin{abstract}
Background: Cowpea (Vigna unguiculata L. Walp.) is a multipurpose legume which has hypocholesterolemic effect. It contains high protein also low fat and is usually consumed as food form by boiling and frying them. Objective: This study aims to investigate the phytosterol composition on boiling and frying process in cowpea also to investigate boiling and frying process effects of cowpea on phytosterol composition. Methods: All of the samples were obtained from markets $X, Y$, and $Z$, East Java. Each sample was extracted with n-hexane, acetone, and chloroform then analysed by Thin Layer Chromatography (TLC), Attenuated Total Reflection-Fourier Transform Infrared (ATR-FTIR), Gas Chromatography-Flame Ionization Detector (GC-FID), and Gas Chromatography-Mass Selective Detector (GC-MSD). Results: The TLC and ATR-FTIR analysis showed the phytosterol content in cowpea. GC-FID showed that cholesterol, campesterol, stigmasterol, and sitosterol were identified in raw and boiled from three markets whilst in fried cowpea from one of the markets only contained stigmasterol and sitosterol. GC-MSD showed cholesterol, campesterol, stigmasterol, and sitosterol were identified in raw, boiled, and fried cowpea. Conclusion: Raw, boiled, and fried cowpea contained the phytosterol composition, such as cholesterol, campesterol, stigmasterol, and sitosterol. Boiling and frying process of cowpea could affect the phytosterol composition.
\end{abstract}

Keywords: Vigna unguiculata L. Walp., cowpea, phytosterol, boiling, frying

\begin{abstract}
Abstrak
Pendahuluan: Kacang tolo (Vigna unguiculata L. Walp.) merupakan polong-polongan multiguna dapat berfungsi sebagai hipokolesterolemik. Kacang tersebut mengandung protein tinggi dan rendah lemak, sebagai bahan makanan dikonsumsi dengan cara direbus maupun digoreng. Tujuan: Penelitian ini bertujuan untuk mengidentifikasi komposisi fitosterol pada kacang tolo yang mentah, direbus, dan digoreng serta mengidentifikasi pengaruh proses perebusan dan penggorengan kacang tolo terhadap komposisi fitosterol. Metode: Seluruh sampel diperoleh dari Pasar X, Y, dan Z, area Jawa Timur. Masing-masing sampel diekstraksi dengan $n$-heksana, aseton, dan kloroform kemudian dianalisis dengan Kromatografi Lapis Tipis (KLT), Attenuated Total Reflection-Fourier Transform Infrared (ATR-FTIR), Kromatografi Gas-Flame Ionization Detector (KG-FID), dan Kromatografi Gas-Mass Selective Detector (KG-MSD). Hasil: Analisis KLT dan ATRFTIR menunjukkan adanya kandungan fitosterol pada kacang tolo. Analisis dengan KG-FID menunjukkan adanya kolesterol, kampesterol, stigmasterol, dan sitosterol pada kacang tolo mentah dan direbus dari Pasar X, Y, dan $\mathrm{Z}$ sedangkan kacang tolo yang digoreng dari Pasar X hanya mengandung stigmasterol dan sitosterol. KGMSD menunjukkan adanya kolesterol, kampesterol, stigmasterol, dan sitosterol pada kacang tolo mentah, direbus, dan digoreng. Kesimpulan: Kacang tolo mentah, direbus, dan digoreng dapat diidentifikasi adanya ke-
\end{abstract}


empat fitosterol, yaitu kolesterol, kampesterol, stigmasterol, dan $\beta$-sitosterol. Proses perebusan dan penggorengan kacang tolo berpengaruh terhadap komposisi fitosterol.

Kata kunci: Vigna unguiculata L. Walp., kacang tolo, fitosterol, perebusan, penggorengan

\section{PENDAHULUAN}

Penyakit Jantung Koroner (PJK) merupakan penyebab utama kematian di seluruh dunia, terhitung sebesar 31,4\% kematian terjadi pada tahun 2012 (Wadhera dkk., 2016). Data riset kesehatan dasar (Riskesdas) 2018 menunjukkan prevalensi PJK di Indonesia berdasarkan diagnosis dokter pada penduduk semua umur sebesar 1,5\% (Badan Litbangkes, 2018). Penyakit ini disebabkan oleh penyempitan dinding arteri koronaria akibat pembentukan plak lemak, sehingga menurunkan aliran darah di pembuluh darah (Setyaji dkk., 2018). Tingginya kadar kolesterol atau disebut juga hiperkolesterolemia merupakan salah satu pemicu terjadinya PJK. Umumnya kondisi hiperkolesterolemia lebih besar terjadi pada wanita $(14,5 \%)$ dibandingkan pria $(8,6 \%)$ (Aurora dkk., 2012).

Salah satu faktor penting untuk menjaga kadar kolesterol di dalam tubuh agar tidak melebihi batas normal adalah jenis makanan. Pada beberapa buah, sayur, gandum, dan kacang-kacangan telah dilaporkan dapat membantu menurunkan kadar kolesterol karena mengandung fitosterol dan serat larut air (soluble fiber) (Ilmi dkk., 2015; Rahman \& Probosari, 2014). Fitosterol merupakan metabolit struktural di membran sel tanaman dan memiliki struktur menyerupai kolesterol. Di dalam tubuh fitosterol dan kolesterol saling bersaing menempati site-aktif enzim pengangkut kolesterol, menyebabkan terjadinya pengurangan jumlah kolesterol yang terserap, sehingga kadarnya di dalam tubuh akan menurun (Talreja dkk., 2017).

Fitosterol dapat ditemukan pada berbagai spesies tanaman diketahui berjumlah lebih dari 200 jenis sterol. $\beta$-sitosterol, kampesterol, dan stigmasterol merupakan jenis sterol paling dominan terdapat di dalam tanaman (Nestola \& Schmidt, 2016). Kandungan sterol total pada kacang-kacangan, diantaranya pistachio $(276 \mathrm{mg} / 100 \mathrm{~g})$, almond $(183 \mathrm{mg} / 100 \mathrm{~g})$, hazelnut $(138 \mathrm{mg} / 100 \mathrm{~g})$, walnut $(127 \mathrm{mg} / 100 \mathrm{~g})$, dan kacang tanah $(104 \mathrm{mg} / 100 \mathrm{~g})$ (Marangoni \& Poli, 2010). Di sisi lain, Indonesia dikenal sebagai negara kaya akan biodiversitasnya, khususnya plasma nutfah hayati dalam hal ini kacang-kacangan, salah satu jenis kacang yang belum banyak dilaporkan kandungan fitosterolnya adalah kacang tolo.
Kacang tolo (Vigna unguiculata L. Walp.) merupakan jenis kacang dengan famili Leguminoceae, mengandung komponen bioaktif, yaitu senyawa fenolik berperan sebagai antioksidan untuk melindungi tubuh terhadap berbagai macam penyakit (Gonçalves dkk., 2016). Kacang ini berpotensi sebagai penurun kadar kolesterol dan kadar glukosa di dalam darah (Kumar dkk., 2013). Di Indonesia, produktivitas kacang ini cukup tinggi dan pemanfaatannya biasanya diolah dengan cara direbus untuk dijadikan sayur atau digoreng. Proses perebusan dilakukan dalam air mendidih suhu $100^{\circ} \mathrm{C}$ selama 30 menit, sedangkan proses penggorengan dengan minyak goreng suhu $190^{\circ} \mathrm{C}$ selama 5 menit (Dovlo dkk., 1976; Mulyatiningsih, 2007).

Penggunaan panas dalam proses pemasakan, seperti perebusan dan penggorengan dapat mempengaruhi nilai gizi bahan pangan, salah satunya fitosterol (Sundari dkk., 2015). Fitosterol tidak akan mengalami perubahan jika diolah pada suhu lebih rendah dari $100^{\circ} \mathrm{C}$, namun apabila dipanaskan pada suhu melebihi $200^{\circ} \mathrm{C}$, maka lebih dari $50 \%$ sterol akan mengalami perubahan (Thanh dkk., 2006). Telah dipublikasikan, hasil penelitian di dalam kacang tanah direbus kadar sterolnya lebih tinggi dua hingga tiga kali dari kacang tanah mentah (Chen dkk., 2009). Peningkatan sterol ini dapat terjadi karena kehilangan karbohidrat, protein atau mineral di dalam sel kacang tersebut (Normén dkk., 1999). Penurunan sterol dapat terjadi pada sampel yang digoreng dan pada suhu $150^{\circ} \mathrm{C}$ (Normén dkk., 1999; Thanh dkk., 2006). Kehilangan beberapa sterol dapat terjadi, diakibatkan oleh pemecahan sel dan jaringan tanaman (Normén dkk., 1999).

Tahap awal identifikasi sterol dapat digunakan Kromatografi Lapis Tipis (KLT) dengan pereaksi penampak noda tertentu untuk mengetahui kandungan steroid di dalam sampel (Indrayanto dkk., 1994). Metode Attenuated Total Reflection-Fourier Transform Infrared (ATR-FTIR) juga dapat digunakan untuk melihat persentase kemiripan suatu senyawa dengan mengkorelasi sampel dengan standar (Sulistyani, 2018). Metode analisis lain umumnya digunakan untuk mengidentifikasi fitosterol baik kualitatif maupun 
kuantitatif adalah Kromatografi Gas-Flame Ionization Detector (KG-FID) (Inchingolo dkk., 2014). Metode ini memiliki resolusi yang baik, keterulangan, reprodusibilitas, presisi serta akurasi tinggi (AlBukhaiti dkk., 2017). Metode lainnya, seperti Kromatografi Gas-Mass Selective Detector (KG-MSD) dapat digunakan untuk mengidentifikasi kemurnian puncak (peak) sterol (Inchingolo dkk., 2014). Mengkaji hal-hal tersebut di atas, penelitian ini bertujuan untuk mengidentifikasi komposisi fitosterol pada kacang tolo mentah, direbus, dan digoreng serta mengidentifikasi pengaruh proses perebusan dan penggorengan kacang tolo terhadap komposisi fitosterol. Dalam hal ini tidak dilakukan analisis perbedaan lokasi pengambilan sampel kacang tolo dari Pasar X, Y, dan Z terhadap komposisi fitosterol.

\section{BAHAN DAN METODE \\ Bahan}

Standar kolesterol, kampesterol, stigmasterol, dan $\beta$-sitosterol (Sigma-Aldrich). Pelarut $n$-heksana p.a, etil asetat p.a, aseton p.a, kloroform p.a, asam klorida p.a, natrium hidroksida p.a, dan plat silika gel 60 F254 diperoleh dari Merck. Penampak noda KLT anisaldehid-asam sulfat dan aquadest.

Sampel kacang tolo berasal dari tiga pasar di Jawa Timur. Pasar X berlokasi di Tegalsari, Surabaya, Pasar Y di Gunung Sari, Surabaya, dan Pasar Z berlokasi di Madyopuro, Malang. Ketiga sampel kacang tersebut telah didentifikasi sebagai Vigna unguiculata L. Walp. oleh Dr. Sugeng Budiharta, M.Sc. dari Lembaga Ilmu Pengetahuan Indonesia (LIPI), Purwodadi, Jawa Timur.

Alat

Chromatographic plate $20 \mathrm{~cm}$ x $10 \mathrm{~cm}$ Silica Gel 60 F254 TLC plate, Merck (Darmstadt, Germany), Camag chamber $20 \mathrm{~cm} \times 10 \mathrm{~cm}$, kapiler $2 \mu \mathrm{L}$. ALPHA II FTIR spektrometer, Hewlett Packard Gas Chromatograph 5890 Series II dengan Flame Ionization Detector (FID) dan kolom HP-5 (crosslinked 5\% phenyl methyl silicone, $25 \mathrm{~m} \mathrm{x} \mathrm{0,32} \mathrm{mm} \mathrm{x}$ 0,17 $\mu \mathrm{m}$ film thickness), Gas Chromatograph 6890N series-Agilent 7697A dengan detektor Agilent 5973 inert MSD dan kolom HP-5MS (30 m x 0,25 mm x $0,25 \mu \mathrm{m}$ ), alat suntik (Hamilton Micro Syringe $10 \mu \mathrm{L}$ ), moisture content (Mettler Toledo), ultrasonic (Branson 1510), vortex (IKA), dan centrifuge (EBA-20).

\section{Metode}

\section{Preparasi sampel}

Kacang tolo mentah digunakan sebagai kontrol, dihomogenisasi dengan blender kemudian diayak. Kacang tolo diolah dengan merebus kacang di air mendidih suhu $100^{\circ} \mathrm{C}$ selama 30 menit sedangkan kacang digoreng diolah dengan menggoreng kacang pada minyak panas suhu $190^{\circ} \mathrm{C}$ selama 5 menit. Setelah dilakukan pemasakan, kacang tolo yang direbus dan digoreng dihomogenisasi dengan blender.

Kadar air pada kacang tolo mentah, direbus, dan digoreng ditentukan dengan alat Mettler Toledo. Hasil pengukuran kadar air digunakan sebagai dasar perhitungan dalam penimbangan kacang agar diperoleh sampel sejumlah kurang lebih 1 gram berat kering. Replikasi dilakukan sebanyak tiga kali pada seluruh sampel.

\section{Ekstraksi fitosterol}

Kacang tolo mentah, direbus, dan digoreng diekstraksi dengan $n$-heksana selama 15 menit menggunakan ultrasonik, di-vorteks 10 menit, dan disentrifugasi pada $2.500 \mathrm{rpm}$ selama 10 menit (tahapan ini diulangi lima kali). Seluruh filtrat dikumpulkan dan diuapkan hingga kering, diperoleh ekstrak $n$-heksana.

Residu kacang tolo diekstraksi dengan aseton menggunakan tahapan yang sama seperti sebelumnya dan diulangi tiga kali. Seluruh filtrat dikumpulkan dan diuapkan hingga kering, diperoleh ekstrak aseton. Selanjutnya residu kacang tolo dihidrolisis dengan asam klorida $(\mathrm{HCl}) 2 \mathrm{~N}$ pada suhu $90-100^{\circ} \mathrm{C}$ selama 30 menit, didinginkan, dinetralisasi dengan natrium hidroksida $(\mathrm{NaOH}) 12 \mathrm{~N}$ hingga $\mathrm{pH} 10$, dan disaring kemudian filtrat diekstraksi dengan kloroform menggunakan tahapan seperti sebelumnya dan diulangi tiga kali. Seluruh filtrat dikumpulkan dan diuapkan hingga kering, diperoleh ekstrak kloroform (Indrayanto dkk., 1994).

\section{Identifikasi fitosterol dengan KLT}

Standar (kolesterol, kampesterol, stigmasterol, dan $\beta$-sitosterol) dan ekstrak $n$-heksana kacang tolo (mentah, direbus, dan digoreng) dilarutkan dengan 0,5 mL kloroform kemudian ditotolkan sebanyak 2-4 $\mu \mathrm{L}$ pada plat silika gel 60 F254 dan dieluasi dengan fase gerak $n$-heksana : etil asetat (4:1) v/v kemudian disemprot dengan pereaksi penampak noda anisaldehid- $\mathrm{H}_{2} \mathrm{SO}_{4}$ (Indrayanto dkk., 1994). 


\section{Identifikasi fitosterol dengan ATR-FTIR}

Standar (kolesterol, kampesterol, stigmasterol, dan $\beta$-sitosterol) dan ekstrak $n$-heksana kacang tolo (mentah, direbus, dan digoreng) dalam kloroform, masing-masing ditempatkan pada plate platinum yang dilengkapi dengan material kristal ZnSe. Ujung kristal diposisikan menyentuh larutan dengan sedikit tekanan untuk memastikan adanya kontak penuh antara larutan dan kristal. Pengukuran dilakukan pada panjang gelombang $4000 \mathrm{~cm}^{-1}$ hingga $600 \mathrm{~cm}^{-1}$. Hasil spekrum inframerah senyawa standar dan sampel dibandingkan kemiripannya sebagai persentase korelasi.

\section{Identifikasi fitosterol dengan KG-FID}

Standar (kolesterol, kampesterol, stigmasterol, dan $\beta$-sitosterol) dan ekstrak (n-heksana, aseton, dan kloroform) kacang tolo (mentah, direbus, dan digoreng) dalam kloroform, diidentifikasi dengan KGFID (Hewlett Packard Gas Chromatograph 5890 Series II, Flame Ionization Detector (FID), dan kolom HP-5 (cross-linked 5\% phenyl methyl silicone, $25 \mathrm{~m} \times$ $0,32 \mathrm{~mm} \times 0,17 \mu \mathrm{m}$ film thickness), gas pembawa helium dengan kecepatan alir $1,7 \mathrm{~kg} / \mathrm{cm}^{2}$, rasio split 25 : 1, diinjeksikan $2 \mu \mathrm{L}$ pada suhu isotermal $290^{\circ} \mathrm{C}$ dengan waktu analisis 30 menit.

Analisis kualitatif pada ekstrak ( $n$-heksana, aseton, dan kloroform) kacang tolo (mentah, direbus, dan digoreng) dilakukan dengan membandingkan waktu retensi relatif sampel dan standar. Jika waktu retensi relatifnya sama, diperkirakan sampel mengandung senyawa yang sama dengan standar (McNair \& Miller, 2009). Hal ini perlu dilakukan analisis lainnya untuk konfirmasi, dalam penelitian ini dengan KG-MSD.

Analisis semi-kuantitatif pada ekstrak $n$-heksana kacang tolo (mentah, direbus, dan digoreng) dihitung dalam persentase relatif fitosterol berdasarkan rumus (McNair \& Miller, 2009):

$\%$ Area $X=\left[\frac{A_{X}}{\sum_{\mathrm{i}}\left(A_{\mathrm{i}}\right)}\right] \times 100$

$\%$ Area $\mathrm{X}=$ persentase relatif sterol $\mathrm{X}(\%)$;

$\mathrm{A}_{\mathrm{x}}=$ Area sterol X; $\mathrm{A}_{\mathrm{i}}=$ Area sterol total.

\section{Identifikasi fitosterol dengan KG-MSD}

Standar (kolesterol, kampesterol, stigmasterol, dan $\beta$-sitosterol) dan ekstrak $n$-heksana kacang tolo (mentah, direbus, dan digoreng) dalam kloroform, diidentifikasi dengan KG-MSD (Gas Chromatograph 6890N series-Agilent 7697A, Agilent 5973 inert MSD equipped with a capillary column $(30 \mathrm{~m} \mathrm{x} 0,25 \mathrm{~mm}$ i.d x $0,25 \mu \mathrm{m}$ film thickness HP-5MS), kecepatan alir $9,2 \mathrm{~mL} / \mathrm{menit}$, splitless, diinjeksikan $0,4 \mu \mathrm{L}$ pada suhu $220-270^{\circ} \mathrm{C}$ dengan kenaikan $10^{\circ} \mathrm{C}$ /menit menggunakan metode Selected Ion Monitoring (SIM).

\section{Analisis data}

Hasil dianalisis dengan Statistical Product and Services Solutions (SPSS) Statistics 17.0 dengan membandingkan proses pemasakan kacang tolo (mentah, direbus, dan digoreng) terhadap komposisi fitosterol menggunakan Multivariate Analysis of Variance (MANOVA). Nilai signifikansi $<0,05$ menunjukkan adanya perbedaan yang signifikan.

\section{HASIL DAN PEMBAHASAN}

Fitosterol terdiri dari kerangka steroid sejumlah 27 hingga 30 atom karbon sebagai kerangka utama dengan gugus hidroksil pada posisi C-3, ikatan rangkap pada posisi $\mathrm{C}-5$, dan rantai samping alifatik pada posisi $\mathrm{C}-17$ (Jannah dkk., 2013; Wadikar dkk., 2017). $\beta$-sitosterol, kampesterol, dan stigmasterol memiliki kelimpahan di alam sekitar 65\%, 30\%, dan 3\% (Brufau dkk., 2008), namun hal ini dipengaruhi jenis tumbuhannya. Kacang-kacangan memiliki komposisi nutrisi yang baik bagi kesehatan, seperti asam lemak tidak jenuh, serat, mineral, vitamin, fitosterol, dan kandungan bioaktif lainnya, mengkonsumsinya secara rutin, dapat menurunkan resiko penyakit kardiovaskular (GuaschFerré dkk., 2017).

Kacang tolo dapat tumbuh dan beradaptasi di daerah tropis dan subtropis dengan kandungan gizi, diantaranya protein $24,6 \mathrm{~g}$, karbohidrat $66,6 \mathrm{~g}$, serat $1,6 \mathrm{~g}$, dan kalsium $0,481 \mathrm{~g}$ per $100 \mathrm{~g}$ kacang tolo mentah. Proses pemasakan kacang tolo, seperti perebusan dan penggorengan dapat mengurangi kandungan gizi di dalam kacang tolo, sehingga sangat penting untuk memperhatikan cara pengolahan bahan pangan sebelum dikonsumsi agar manfaat nutrisi yang terkandung di dalamnya dapat diperoleh secara optimal (DepKes RI, 1995). Kacang ini oleh masyarakat diolah sebagai bahan campuran pada makanan lodeh, gudeg, lepet ketan, dan bubur juga disajikan dengan digoreng sebagai makanan ringan.

Pada penelitian ini kacang tolo mentah, direbus, dan digoreng dari Pasar X, Y, dan Z diambil untuk mewakili kacang tolo yang dipasarkan di masyarakat namun demikian dalam hal ini tidak dilakukan analisis perbedaan lokasi kacang tolo terhadap komposisi fitosterol. Kacang tolo dihomogenisasikan hingga halus menjadi serbuk kemudian kadar air diukur untuk memperhitungkan penimbangan berat kering sampel pada tahap ekstraksi. Hasil kadar air dan penimbangan kacang tolo mentah, direbus, dan digoreng dapat diamati pada Tabel 1. 
Tabel 1. Kadar air dan penimbangan kacang tolo mentah, direbus, dan digoreng

\begin{tabular}{cccccc}
\hline Pasar & Kacang tolo & Kadar air & \multicolumn{3}{c}{ Berat kacang (g) } \\
\cline { 4 - 6 } & & $(\%)$ & I & II & III \\
\hline \multirow{3}{*}{$\mathrm{X}$} & Mentah & $9,46 \pm 1,45$ & 1,0020 & 1,0025 & 1,0020 \\
& Direbus & $57,76 \pm 0,52$ & 2,3531 & 2,3736 & 2,3593 \\
& Digoreng & $1,18 \pm 0,98$ & 1,1029 & 1,1014 & 1,1012 \\
\hline \multirow{3}{*}{$\mathrm{Y}$} & Mentah & $9,45 \pm 0,11$ & 1,1913 & 1,2001 & 1,1964 \\
& Direbus & $52,54 \pm 0,20$ & 2,1941 & 2,1892 & 2,1909 \\
& Digoreng & $1,58 \pm 0,01$ & 1,0254 & 1,0233 & 1,0239 \\
\hline \multirow{3}{*}{$\mathrm{Z}$} & Mentah & $12,22 \pm 0,04$ & 1,2387 & 1,2453 & 1,2316 \\
& Direbus & $56,50 \pm 0,31$ & 2,4585 & 2,4348 & 2,4394 \\
& Digoreng & $3,18 \pm 0,04$ & 1,1247 & 1,1299 & 1,1275 \\
\hline
\end{tabular}

Kadar air terendah pada kacang tolo digoreng, dibawah 5\% disebabkan oleh proses oksidasi cairan pada bahan pangan selama proses penggorengan, sehingga menghasilkan olahan kering (Guallar dkk., 2007). Kadar air di atas $50 \%$ pada kacang tolo direbus merupakan kadar air tertinggi karena terjadinya proses difusi panas dan massa air pada matriks kacang, sehingga kadar air meningkat (Pangastuti dkk., 2013). Kandungan air dalam sampel melebihi $18 \%$ dapat menurunkan efisiensi ekstraksi (Nagy \& Simándi, 2008). Perbedaan kepolaran antara air, bersifat polar, sebagai media proses perebusan dan $n$-heksana, bersifat non-polar, sebagai pelarut pengekstraksi dapat menurunkan efisiensi proses ekstraksi. Upaya yang dapat dilakukan untuk memperoleh hasil ekstraksi secara optimal, melalui proses pengeringan ulang pada suhu $45-50^{\circ} \mathrm{C}$ setelah sampel ditimbang secara seksama. Hal ini bertujuan untuk memperoleh kadar air kurang dari $18 \%$ pada kacang tolo direbus.

Proses ekstraksi mengacu pada prosedur Indrayanto dkk. (1994), menggunakan pelarut $n$ heksana untuk mengekstraksi fitosterol bebas, selanjutnya digunakan pelarut aseton untuk memastikan fitosterol bebas telah terekstraksi sempurna pada ekstraksi sebelumnya. Selain fitosterol bebas, fitosterol terdapat dalam bentuk terikat (teresterifikasi atau terglikosilasi), sehingga dilakukan pemutusan ikatan ester pada fitosterol terikat melalui tahapan hidrolisis menggunakan $\mathrm{HCl} 2 \mathrm{~N}$ pada suhu 90-100 ${ }^{\circ} \mathrm{C}$ (Indrayanto dkk., 1994; Moreau dkk., 2002). Proses netralisasi dengan $\mathrm{NaOH} 12 \mathrm{~N}$ dilakukan setelahnya untuk memisahkan senyawa asam karboksilat dari proses hidrolisis agar membentuk garam, sehingga asam karboksilat ini tidak ikut terekstraksi dan akan terlarut dalam fase air. Pelarut kloroform digunakan dalam proses ekstraksi berikutnya untuk memperoleh fitosterol bebas yang telah terlepas dari senyawa lain (Indrayanto dkk., 1994).
Kromatografi lapis tipis digunakan dalam identifikasi awal secara kualitatif untuk mengetahui keberadaan fitosterol di dalam sampel. Dalam pengujian ini, noda sampel berwarna ungu dengan nilai Retention Factor (Rf) sampel sama dengan standar, yaitu stigmasterol sebagai pembanding. Bercak noda berwarna ungu menandakan adanya terpenoid atau steroid (Sherma \& Fried, 2003). Inti struktur fitosterol adalah steroid dan berdasarkan hasil tersebut keseluruhan sampel mengandung terpenoid atau steroid. Kandungan yang diduga terdapat di dalam sampel adalah golongan sterol. Pemastian keberadaan kolesterol, kampesterol, stigmasterol, dan $\beta$-sitosterol di dalam sampel dapat diidentifikasi dengan metode analisis selanjutnya.

Identifikasi fitosterol dengan ATR-FTIR digunakan untuk memastikan keberadaan fitosterol pada proses perebusan dan penggorengan kacang tolo. Kolesterol memberikan serapan spesifik, gugus $\mathrm{O}-\mathrm{H}$ pada $3430 \mathrm{~cm}^{-1}$, gugus $\mathrm{C}-\mathrm{O}$ pada $1055 \mathrm{~cm}^{-1}$, gugus $\mathrm{C}=\mathrm{C}$ pada $1464 \mathrm{~cm}^{-1}$, dan gugus $\mathrm{C}-\mathrm{C}$ pada $955 \mathrm{~cm}^{-1}$ (Ferrero dkk., 2015). Stigmasterol memberikan serapan spesifik, gugus $\mathrm{O}-\mathrm{H}$ pada $3335 \mathrm{~cm}^{-1}$, gugus $\mathrm{C}=\mathrm{C}$ pada $1667 \mathrm{~cm}^{-1}$, dan $\mathrm{C}-\mathrm{H}$ pada $879 \mathrm{~cm}^{-1}$ sedangkan $\beta$ sitosterol, gugus $\mathrm{O}-\mathrm{H}$ pada $3331 \mathrm{~cm}^{-1}$, gugus $\mathrm{C}=\mathrm{C}$ pada $1654 \mathrm{~cm}^{-1}$, dan gugus C-C pada $1062 \mathrm{~cm}^{-1}$ (Rajput \& Rajput, 2012). Hasil identifikasi spektra inframerah ATR-FTIR standar fitosterol (kolesterol, kampesterol, stigmasterol, dan $\beta$-sitosterol) menunjukkan serapan spesifik, gugus $\mathrm{O}-\mathrm{H}$ pada $3020 \mathrm{~cm}^{-1}$, gugus $\mathrm{C}-\mathrm{O}$ pada $1214 \mathrm{~cm}^{-1}$, gugus $\mathrm{C}=\mathrm{C}$ pada $1474 \mathrm{~cm}^{-1}$, dan gugus $\mathrm{C}-\mathrm{C}$ pada $928 \mathrm{~cm}^{-1}$. Kemiripan spektra inframerah ATRFTIR pada ke-empat standar fitosterol disebabkan oleh struktur inti steroid di dalam senyawa tersebut relatif sama. Spektra inframerah ATR-FTIR kacang tolo mentah menunjukkan serapan spesifik, gugus $\mathrm{O}-\mathrm{H}$ pada $3019 \mathrm{~cm}^{-1}$, gugus C-O pada $1214 \mathrm{~cm}^{-1}$, gugus $\mathrm{C}=\mathrm{C}$ pada $1467 \mathrm{~cm}^{-1}$, dan gugus C-C pada $929 \mathrm{~cm}^{-1}$. Kacang tolo direbus memberikan serapan spesifik, 
gugus $\mathrm{O}-\mathrm{H}$ pada $3019 \mathrm{~cm}^{-1}$, gugus C-O pada $1214 \mathrm{~cm}^{-}$ ${ }^{1}$, gugus $\mathrm{C}=\mathrm{C}$ pada $1476 \mathrm{~cm}^{-1}$, dan gugus $\mathrm{C}-\mathrm{C}$ pada 929 $\mathrm{cm}^{-1}$. Kacang tolo digoreng menghasilkan serapan spesifik, gugus O-H pada $3019 \mathrm{~cm}^{-1}$, gugus C-O pada $1214 \mathrm{~cm}^{-1}$, gugus $\mathrm{C}=\mathrm{C}$ pada $1465 \mathrm{~cm}^{-1}$, dan gugus $\mathrm{C}-\mathrm{C}$ pada $928 \mathrm{~cm}^{-1}$. Perbedaan bilangan gelombang pada standar dan sampel disebabkan karena adanya pengaruh matriks yang terdapat pada sampel (Duarte dkk., 2002). Hasil identifikasi spektra inframerah ATR-FTIR pada standar dan sampel dianalisis kemiripannya menggunakan parameter persen korelasi. Dalam pengujian ini, kacang tolo mentah dan direbus menunjukkan persen korelasi $100 \%$ terhadap standar sedangkan persen korelasi kacang tolo digoreng sebesar $99,7 \%$. Hal tersebut disebabkan oleh pengaruh minyak, sebagai media proses penggorengan, kemungkinan ikut masuk ke dalam matriks, sehingga mempengaruhi hasil analisis ATR-FTIR. Salah satu contoh hasil persen korelasi antara kacang tolo mentah terhadap stigmasterol dapat diamati pada Gambar 1.

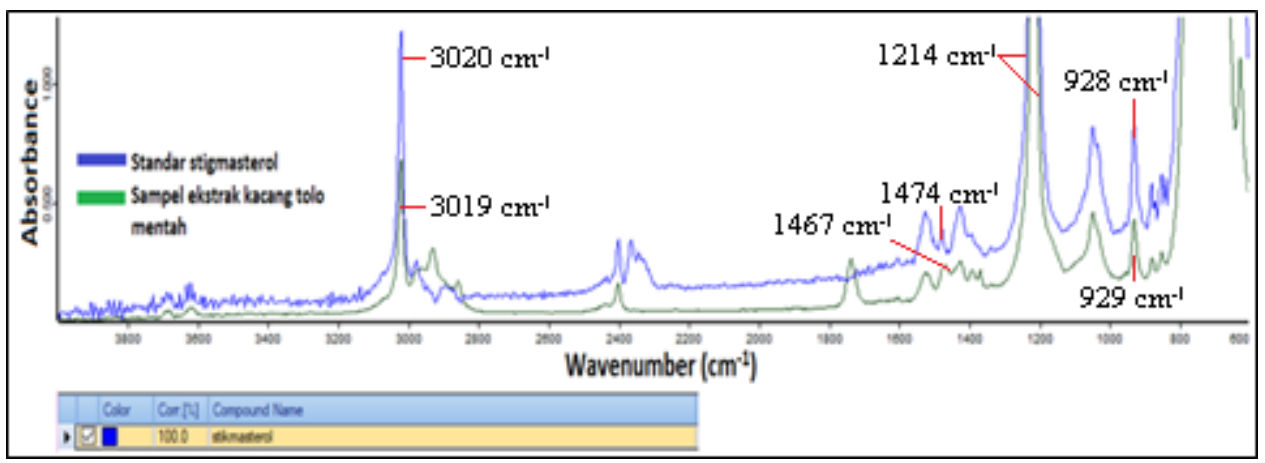

Gambar 1. Spekta inframerah ATR-FTIR persen korelasi kacang tolo mentah dan stigmasterol

Analisis kualitatif menggunakan KG-FID dilakukan dengan membandingkan waktu retensi relatif sampel dan standar. Waktu retensi relatif standar fitosterol dan sampel dari ekstrak $n$-heksana kacang tolo mentah, direbus, dan digoreng dapat diamati pada Tabel 2 dan Tabel 3. Dalam pengujian ini, waktu retensi relatif sampel dan standar adalah sama, sehingga sampel memiliki probabilitas senyawa sterol yang sama dengan standar. Kromatogram KG-FID standar fitosterol dan salah satu contoh kromatogram KG-FID ekstrak $n$-heksana kacang tolo mentah, direbus, dan digoreng disajikan pada Gambar 2.

Tabel 2. Waktu retensi relatif standar fitosterol

\begin{tabular}{ccc}
\hline Standar & $\begin{array}{c}\text { Waktu retensi standar } \\
\text { (menit) }\end{array}$ & $\begin{array}{c}\text { Waktu retensi relatif } \\
\text { standar* }\end{array}$ \\
\hline Kolesterol & 19,733 & 0,80 \\
Kampesterol & 23,525 & 0,95 \\
Stigmasterol & 24,768 & 1,00 \\
$\beta$-Sitosterol & 27,278 & 1,10 \\
\hline
\end{tabular}

*Waktu retensi relatif dihitung dengan membandingkan waktu retensi tiap sterol terhadap waktu retensi stigmasterol 
I.

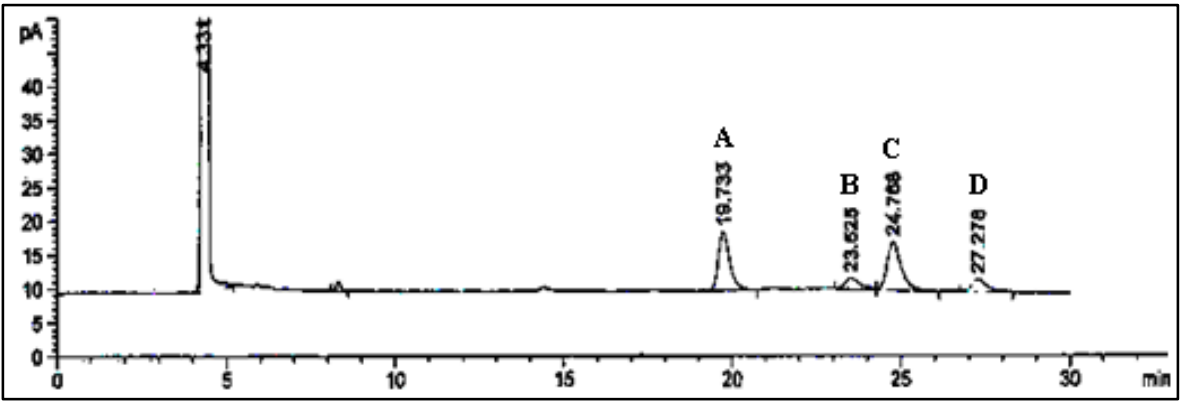

II.

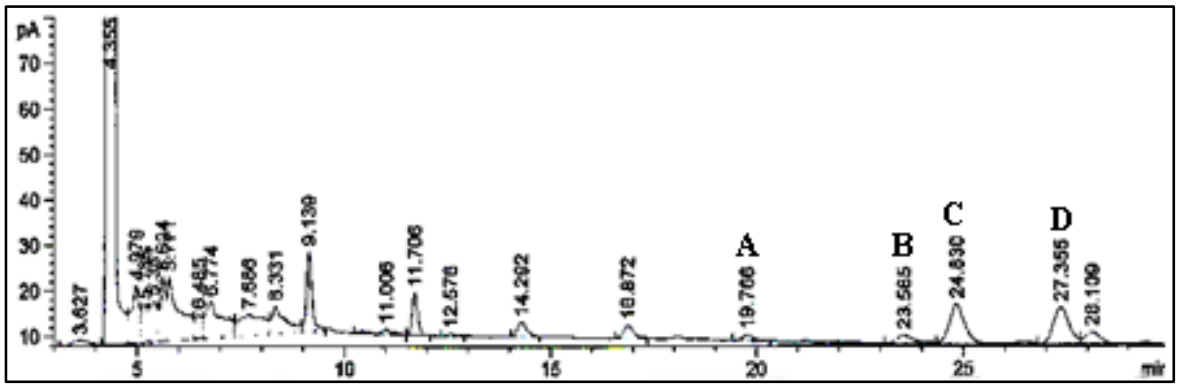

III.
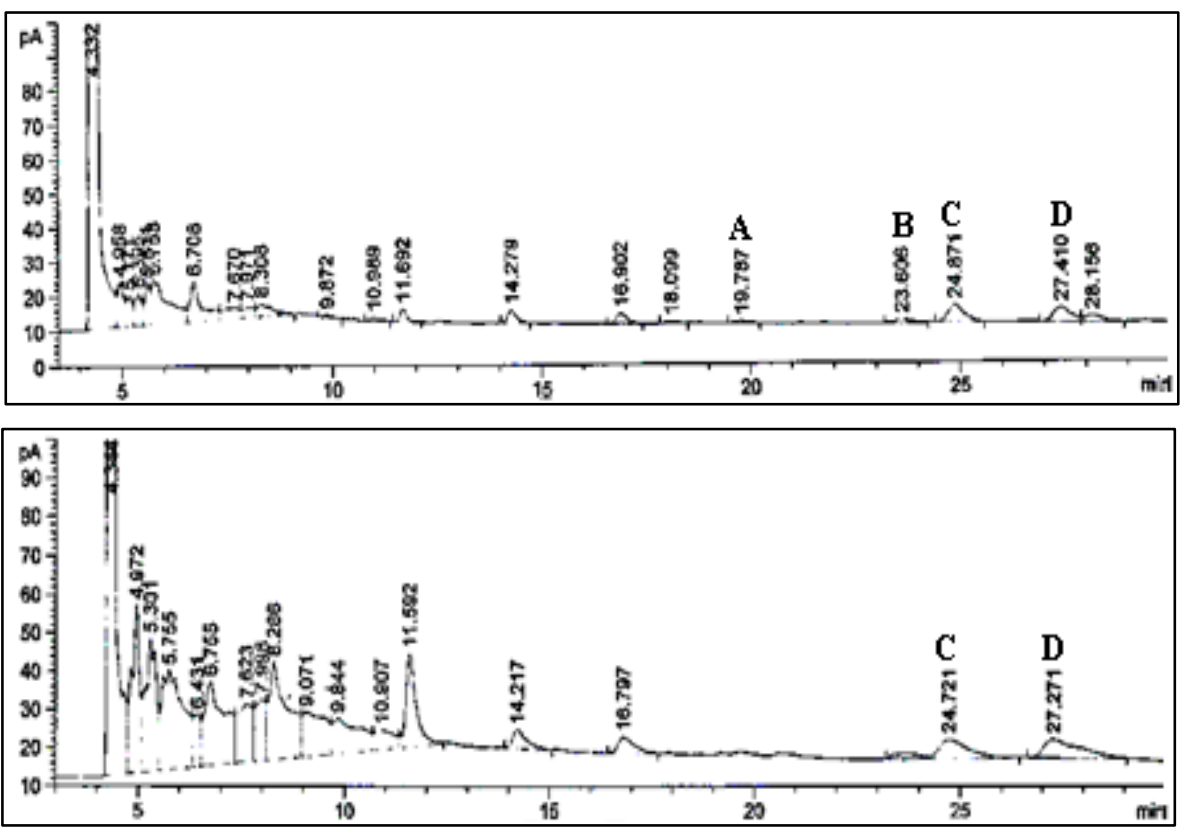

Gambar 2. Kromatogram KG-FID (Hewlett packard gas chromatograph 5890 series II, flame ionization detector (FID), kolom HP-5 (cross-linked 5\% phenyl methyl silicone, $25 \mathrm{~m} \times 0.32 \mathrm{~mm} \times 0,17 \mu \mathrm{m}$ film thickness), gas pembawa helium kecepatan alir $1,7 \mathrm{Kg} / \mathrm{cm}^{2}$, rasio split $25: 1$, volume injeksi $2 \mu \mathrm{L}$, suhu isotermal $290^{\circ} \mathrm{C}$ selama 30 menit. standar fitosterol (I) dan ekstrak $n$-heksana kacang tolo mentah (II), direbus (III), digoreng (IV). kolesterol (A), kampesterol (B), stigmasterol (C), dan $\beta$-sitosterol (D) 
Tabel 3. Waktu retensi relatif ekstrak $n$-heksana kacang tolo mentah, direbus, dan digoreng

\begin{tabular}{|c|c|c|c|c|c|c|c|c|c|c|c|c|c|}
\hline \multirow{3}{*}{ Pasar } & \multirow{3}{*}{ Kacang tolo } & \multicolumn{12}{|c|}{ Waktu retensi (menit) } \\
\hline & & \multicolumn{3}{|c|}{ Kolesterol } & \multicolumn{3}{|c|}{ Kampesterol } & \multicolumn{3}{|c|}{ Stigmasterol } & \multicolumn{3}{|c|}{$\beta$-sitosterol } \\
\hline & & $\mathrm{I}$ & II & III & $\mathrm{I}$ & II & III & $\mathrm{I}$ & II & III & $\mathrm{I}$ & II & III \\
\hline \multirow{3}{*}{$X$} & Mentah & 19,768 & 19,751 & 19,766 & 23,568 & 23,545 & 23,565 & 24,844 & 24,816 & 24,830 & 27,369 & 27,342 & 27,355 \\
\hline & Direbus & 19,744 & 19,773 & 19,787 & 23,530 & 23,578 & 23,606 & 24,801 & 24,837 & 24,871 & 27,321 & 27,355 & 27,410 \\
\hline & Digoreng & - & - & - & - & - & - & 24,721 & 24,667 & 24,341 & 27,271 & 27,190 & 26,833 \\
\hline \multirow{3}{*}{ Y } & Mentah & 19,712 & 19,882 & 19,780 & 23,509 & 23,554 & 23,559 & 24,776 & 24,861 & 24,820 & 27,039 & 27,404 & 27,340 \\
\hline & Direbus & 19,746 & 19,848 & 19,832 & 23,543 & 23,663 & 23,618 & 24,802 & 24,900 & 24,878 & 27,326 & 27,450 & 27,422 \\
\hline & Digoreng & 19,702 & 19,726 & 19,833 & 23,511 & 23,559 & 23,680 & 24,761 & 24,831 & 24,946 & 27,261 & 27,331 & 27,486 \\
\hline \multirow{3}{*}{$\mathrm{Z}$} & Mentah & 19,786 & 19,717 & 19,721 & 23,620 & 23,500 & 23,491 & 24,873 & 24,759 & 24,751 & 27,390 & 27,273 & 27,274 \\
\hline & Direbus & 19,793 & 19,811 & 19,773 & 23,619 & 23,629 & 23,581 & 24,873 & 24,888 & 24,840 & 27,412 & 27,413 & 27,374 \\
\hline & Digoreng & 19,684 & 19,745 & 19,883 & 23,493 & 23,596 & 23,680 & 24,739 & 24,830 & 24,946 & 27,247 & 27,367 & 27,486 \\
\hline Waktu & ensi relatif* & & 0,80 & & & 0,95 & & & 1,00 & & & 1,10 & \\
\hline
\end{tabular}

*Waktu retensi relatif sampel dihitung dengan membandingkan waktu retensi tiap sterol terhadap waktu retensi stigmasterol

Tabel 4. Persentase fitosterol* ekstrak $n$-heksana kacang tolo mentah, direbus, dan digoreng

\begin{tabular}{ccccccccccccccc}
\hline \multirow{2}{*}{ Pasar } & Kacang tolo & \multicolumn{3}{c}{ Kolesterol (\%) } & \multicolumn{3}{c}{ Kampesterol (\%) } & \multicolumn{3}{c}{ Stigmasterol (\%) } \\
\cline { 3 - 11 } & & I & II & III & I & II & III & I & II & III & I & II & III \\
\hline \multirow{3}{*}{ X } & Mentah & 5,24 & 3,97 & 4,67 & 10,05 & 10,56 & 10,95 & 41,80 & 42,69 & 42,69 & 42,91 & 41,69 & 41,69 \\
& Direbus & 5,92 & 5,33 & 4,86 & 10,43 & 9,89 & 10,16 & 43,35 & 44,87 & 44,58 & 40,30 & 39,91 & 40,40 \\
& Digoreng & - & - & - & - & - & - & 50,09 & 45,27 & 50,23 & 49,91 & 54,73 & 49,77 \\
\hline \multirow{3}{*}{ Y } & Mentah & 4,57 & 9,22 & 5,00 & 10,40 & 8,50 & 9,83 & 44,66 & 41,62 & 44,27 & 40,38 & 40,66 & 40,90 \\
& Direbus & 19,98 & 5,53 & 5,40 & 9,66 & 9,24 & 7,92 & 37,02 & 47,73 & 45,24 & 33,34 & 37,50 & 41,44 \\
& Digoreng & 2,74 & 5,65 & 16,61 & 11,17 & 10,26 & 14,56 & 39,40 & 37,27 & 29,97 & 46,69 & 46,82 & 38,86 \\
\hline \multirow{3}{*}{$Z$} & Mentah & 4,81 & 5,22 & 4,40 & 9,53 & 9,78 & 10,37 & 45,18 & 45,91 & 46,42 & 40,49 & 39,09 & 38,81 \\
& Direbus & 17,56 & 6,51 & 19,76 & 9,81 & 9,45 & 9,15 & 39,27 & 45,26 & 38,02 & 33,36 & 38,78 & 33,07 \\
& Digoreng & 13,46 & 14,90 & 16,61 & 10,02 & 21,07 & 14,56 & 31,10 & 27,36 & 29,97 & 45,52 & 36,66 & 38,86 \\
\hline
\end{tabular}

$*$ Persentase fitosterol dihitung berdasarkan area sterol yang terdeteksi dibandingkan dengan area sterol total yang terdeteksi 
Tabel 4 menunjukkan komposisi fitosterol pada ekstrak $n$-heksana di dalam kacang tolo mentah, direbus, dan digoreng. Komposisi fitosterol diperoleh dari hasil perhitungan area kromatogram KG-FID secara semi-kuantitatif sebagai kadar relatif fitosterol. Cara perhitungan mengacu pada McNair \& Miller (2009) dan juga telah digunakan pada publikasi Kaloustian dkk. (2008) dengan membandingkan area sterol " $\mathrm{x}$ " terhadap area sterol total. Kacang tolo digoreng dari Pasar X memiliki perbedaan komposisi fitosterol dibandingkan Pasar $\mathrm{Y}$ dan $\mathrm{Z}$, yaitu hanya mengandung stigmasterol dan sitosterol. Perbedaan tersebut dapat disebabkan oleh proses difusi panas dengan mekanisme transfer panas dari media pemasakan ke dalam bahan disertai laju panas terdifusi keluar masuk ke dalam bahan secara natural untuk mendistribusikan panas ke seluruh bagian produk. Proses ini mengakibatkan terbawanya fitosterol ke media pemasakan, yaitu minyak, sehingga fitosterol berkurang saat proses penggorengan (Fontana dkk., 2001). Terjadinya proses degradasi saat penggorengan pada suhu tinggi juga dapat menyebabkan berkurangnya fitosterol pada bahan (Cantrill \& Kawamura, 2008). Pada pengujian ini dilakukan replikasi tiga kali, meskipun bersifat semi kuantitatif, namun pada beberapa sampel terlihat data persentase fitosterol yang cukup bervariasi. Hal ini berkaitan dengan analisis fitosterol dalam sampel dari bahan alam, yaitu kacang tolo dengan kandungan fitosterol relatif kecil, sehingga untuk bahan alam Horwitz (2013) memberikan kelonggaran persen rekoveri cukup lebar, yaitu $80-110 \%$.

Dalam pengujian ini, ekstrak aseton dan kloroform kacang tolo mentah, direbus, dan digoreng menunjukkan tidak adanya puncak sterol yang terdeteksi. Hal tersebut membuktikan seluruh sterol telah terekstraksi sempurna pada ekstraksi $n$-heksana sebelumnya dan tidak terdapat fitosterol terikat di dalam ekstrak kloroform.

Penelitian ini bertujuan untuk mengidentifikasi pengaruh proses perebusan dan penggorengan kacang tolo terhadap komposisi fitosterol. Analisis data menggunakan uji MANOVA dengan membandingkan proses pemasakan (mentah, direbus, dan digoreng) terhadap area fitosterol (kolesterol, kampesterol, stigmasterol, dan $\beta$-sitosterol) dari kromatogram KGFID. Hasil analisis statistika menunjukkan perbedaan signifikan pada area sitosterol antara kacang tolo direbus dan digoreng sedangkan pada area kolesterol, kampesterol, dan stigmasterol antara kacang tolo direbus dan digoreng tidak berbeda signifikan. Komposisi fitosterol pada kacang tolo direbus sama dengan kacang tolo mentah dan keduanya tidak berbeda signifikan. Sementara itu, perbedaan komposisi fitosterol pada kacang tolo direbus dan kacang tolo digoreng dapat disebabkan perbedaan suhu saat proses pemasakan kacang tolo, diantaranya proses perebusan pada suhu $100^{\circ} \mathrm{C}$ sedangkan proses penggorengan pada suhu $190^{\circ} \mathrm{C}$.

Penentuan senyawa hasil analisis KG-MSD mengacu pada European Commission Decision 2002/657/EC, yaitu dalam identifikasi harus menunjukkan kesamaan empat fragmen spesifik dengan intensitas yang tidak jauh berbeda dengan pembanding database. Dalam pengujian ini digunakan database Wiley 7.0 dari instrumen KG-MSD. Ekstrak $n$-heksana kacang tolo mentah, direbus, dan digoreng dianalisis dengan KG-MSD. Kacang tolo mentah dijadikan acuan sebagai pembanding dengan proses pemasakan, yaitu perebusan dan penggorengan. Hasil analisis menunjukkan inti steroid pada fragmen ion spesifik di m/z 255, 271, dan 273 (Zhao dkk., 1989). Senyawa fitosterol pada ekstrak $n$-heksana kacang tolo mentah, direbus, dan digoreng memiliki fragmen khas dan dapat diamati pada Tabel 5. Fragmen tersebut digunakan untuk mengkonfirmasi kandungan fitosterol dari pengujian KLT dan KG-FID. Dalam pengujian KG-MSD membuktikan bahwa kacang tolo mentah, direbus, dan digoreng mengandung fitosterol, yaitu kolesterol, kampesterol, stigmasterol, dan $\beta$-sitosterol. 
Tabel 5. Ion molekular dan fragmentasi kolesterol, kampesterol, stigmasterol, dan $\beta$-sitosterol yang teridentifikasi pada

\begin{tabular}{|c|c|c|c|}
\hline \multirow{2}{*}{ Ion molekular $[\mathrm{M}]+$ dan fragmen } & \multicolumn{3}{|c|}{ Senyawa pada kacang tolo $(\mathrm{m} / \mathrm{z})$} \\
\hline & Mentah & Direbus & Digoreng \\
\hline \multicolumn{4}{|l|}{ Kolesterol } \\
\hline$[\mathrm{M}]^{+}$ & 386 & 386 & - \\
\hline$\left[\mathrm{M}-\mathrm{H}_{2} \mathrm{O}\right]^{+}$ & 368 & 368 & - \\
\hline$\left[\mathrm{M}-\mathrm{C}_{5} \mathrm{H}_{7}-\mathrm{H}_{2} \mathrm{O}\right]^{+}$ & 303 & 303 & - \\
\hline$[\mathrm{M} \text {-side chain }]^{+}$ & 275 & 275 & - \\
\hline$\left[\mathrm{M} \text {-side chain- } \mathrm{H}_{2} \mathrm{O}\right]^{+}$ & 255 & 255 & - \\
\hline \multicolumn{4}{|l|}{ Kampesterol } \\
\hline$[\mathrm{M}]^{+}$ & 400 & 400 & - \\
\hline$\left[\mathrm{M}-\mathrm{H}_{2} \mathrm{O}\right]^{+}$ & 382 & 382 & - \\
\hline$\left[\mathrm{M}-\mathrm{C}_{5} \mathrm{H}_{7}-\mathrm{H}_{2} \mathrm{O}\right]^{+}$ & 315 & - & - \\
\hline$[\mathrm{M} \text {-side chain }]^{+}$ & 273 & 273 & - \\
\hline$\left[\mathrm{M} \text {-side chain- } \mathrm{H}_{2} \mathrm{O}\right]^{+}$ & 255 & 255 & - \\
\hline \multicolumn{4}{|l|}{ Stigmasterol } \\
\hline$[\mathrm{M}]^{+}$ & 412 & 412 & 412 \\
\hline$\left[\mathrm{M}-\mathrm{H}_{2} \mathrm{O}\right]^{+}$ & 394 & 394 & - \\
\hline$\left[\mathrm{M}-\mathrm{C}_{3} \mathrm{H}_{7}-\mathrm{H}_{2} \mathrm{O}\right]^{+}$ & 351 & 351 & 351 \\
\hline$[\mathrm{M} \text {-side chain-2H }]^{+}$ & 271 & 271 & 271 \\
\hline$\left[\mathrm{M} \text {-side chain- } \mathrm{H}_{2} \mathrm{O}\right]^{+}$ & 255 & 255 & 255 \\
\hline \multicolumn{4}{|l|}{$\beta$-sitosterol } \\
\hline$[\mathrm{M}]^{+}$ & 414 & 414 & 414 \\
\hline$\left[\mathrm{M}-\mathrm{H}_{2} \mathrm{O}\right]^{+}$ & 396 & 396 & 396 \\
\hline$\left[\mathrm{M}-\mathrm{C}_{3} \mathrm{H}_{7}-\mathrm{H}_{2} \mathrm{O}\right]^{+}$ & 303 & 303 & 303 \\
\hline$[\mathrm{M} \text {-side chain-2H }]^{+}$ & 273 & - & 273 \\
\hline$\left[\mathrm{M} \text {-side chain- } \mathrm{H}_{2} \mathrm{O}\right]^{+}$ & 255 & 255 & 255 \\
\hline
\end{tabular}

\section{KESIMPULAN}

Kacang tolo mentah, direbus, dan digoreng dapat diidentifikasi adanya keempat fitosterol, yaitu kolesterol, kampesterol, stigmasterol, dan $\beta$-sitosterol. Proses perebusan dan penggorengan kacang tolo berpengaruh terhadap komposisi fitosterol.

\section{UCAPAN TERIMAKASIH}

Penulis berterimakasih kepada Prof. Dr. rer.nat. Gunawan Indrayanto yang telah memfasilitasi penyediaan keempat senyawa standar fitosterol (Sigma-Aldrich).

\section{DAFTAR PUSTAKA}

Al-Bukhaiti, W. Q., Noman, A., Qasim, A. S. \& AlFarga, A. (2017). Gas Chromatography: Principles, Advantages and Applications in Food Analysis. International Journal of Agriculture Innovations and Research; 6; 123128.

Aurora, R. G., Sinambela, A. \& Noviyanti, C. H. (2012). Peran Konseling Berkelanjutan pada Penanganan Pasien Hiperkolesterolemia. Journal of the Indonesian Medical Association; 62; 194-201.
Badan Penelitian dan Pengembangan Kesehatan (Badan Litbangkes). (2018). Hasil Utama Riset Kesehatan Dasar 2018. Jakarta: Kementerian Kesehatan RI.

Brufau, G., Canela, M. A. \& Rafecas, M. (2008). Phytosterols: Physiologic and Metabolic Aspects Related to Cholesterol-Lowering Properties. Nutrition Research; 28; 217-225.

Cantrill, R. \& Kawamura, Y. (2008). Phytosterols, Phytostanols, and Their Esters. London: Forbes Medi-Tech Inc.

Chen, Q., Gruber, H., Pakenham, C., Ratnayake, W. M. N. \& Scoggan, K. A. (2009). Dietary Phytosterols and Phytostanols Alter the Expression of Sterol-Regulatory Genes in SHRSP and WKY Inbred Rats. Annals of Nutrition and Metabolism; 55; 341-350.

Departemen Kesehatan RI (DepKes RI). (1995). Daftar Komposisi Zat Gizi Pangan Indonesia. Jakarta: Direktorat Jenderal Pembinaan Kesehatan Masyarakat.

Dovlo, F. E., Williams, C. E. \& Zoaka, L. (1976). Cowpeas: Home Preparation and Use in West Africa. Canada: International Development Research Centre. 
Duarte, M. L., Ferreira, M. C., Marvão, M. R. \& Rocha, J. (2002). An Optimised Method to Determine the Degree of Acetylation of Chitin and Chitosan by FTIR Spectroscopy. International Journal of Biological Macromolecules; 31; 1-8.

Ferrero, F., Mossotti, R., Innocenti, R., Coppa, F. \& Periolatto, M. (2015). Enzyme-aided Wool Dyeing: Influence of Internal Lipids. Fibers and Polymers; 16; 363-369.

Fontana, A. J., Wacker, B. \& Champbell, C. S. (2001). Simultaneous Thermal Conductivity, Thermal Resistivity, and Thermal Diffusivity Measurement of Selected Foods and Soils California, USA. American Society of Agricultural and Biological Engineers; 95; 4548.

Gonçalves, A., Goufo, P., Barros, A., DomínguezPerles, R., Trindade, H., Rosa, E. A. S., Ferreira, L. \& Rodrigues, M. (2016). Cowpea (Vigna unguiculata L. Walp.), a Renewed Multipurpose Crop for a More Sustainable Agri-food System: Nutritional Advantages and Constraints. Journal of the Science of Food and Agriculture; 96; 2941-2951.

Guallar, C. P., Rodriguez, A. F., Fornes, N. S., Banegas, J. R., Etxezarreta, P. A. \& Ardanaz, E. (2007). Intake of Fried Foods is Associated with Obesity in the Cohort of Spanish Adults from the Europian Prospective Investigation into Cancer and Nutrition. American Journal of Clinical Nutrition; 86; 198-205.

Guasch-Ferré, M., Liu, X., Malik, V. S., Sun, Q., Willett, W. C., Manson, J. A. E., Rexrode, K. M., Li, Y., Hu, F. B. \& Bhupathiraju, S. N. (2017). Nut Consumption and Risk of Cardiovascular Disease. Journal of the American College of Cardiology; 70; 25192532.

Horwitz. (2013). AOAC Guidelines for Single Laboratory Validation of Chemical Methods for Dietary Supplements and Botanicals. http://www.aoac.org/Official_Methods/slv_guid elines.pdf. Accessed: 10 Januari 2020.

Ilmi, I. M. B., Ali, K. \& Sri, A. M. (2015). Cara Pengolahan Makanan Rumah Tangga Indonesia. Jakarta: Indonesian Food Technology.

Inchingolo, R., Cardenia, V. \& Rodriguez-Estrada, M. T. (2014). Analysis of Phytosterols and Phytostanols in Enriched Dairy Products by Fast
Gas Chromatography with Mass Spectrometry. Journal of Separation Science; 37; 2911-2919.

Indrayanto, G., Studiawan, H. \& Cholies, N. (1994). Isolation and Quantitation of Manogenin and Kammogenin from Callus Cultures of Agave amaniensis. Phytochemical Analysis; 5; 24-26.

Jannah, H., Sudarma, I. M. \& Andayani, Y. (2013). Analisis Senyawa Fitosterol dalam Ekstrak Buah Buncis (Phaseolus vulgaris L.). Journal Chemical Program; 6; 70-75.

Kaloustian, J., Alhanout, K., Amiot-Carlin, M. J., Lairon, D., Portugal, H. \& Nicolay, A. (2008). Effect of Water Cooking on Free Phytosterol Levels in Beans and Vegetables. Food Chemistry; 107; 1379-1386.

Kumar, S., Jyotirmayee, K. \& Sarangi, M. (2013). Thin Layer Chromatography: a Tool of Biotechnology for Isolation of Bioactive Compounds from Medical Plants. International Journal of Pharmaceutical Sciences Review and Research; 18; 126-132.

Marangoni, F. \& Poli, A. (2010). Phytosterols and Cardiovascular Health. Pharmacological Research; 61; 193-199.

McNair, H. M. \& Miller, J. M. (2009). Chapter 8. Qualitative and quantitave analysis. In: Basic Gas Chromatography. New York: John Willey $\&$ Sons, Inc.

Moreau, R. A., Whitaker, B. D. \& Hicks, K. B. (2002). Phytosterols, Phytostanols, and Their Conjugates in Foods: Structural Diversity, Quantitatively Analysis, and Health-promoting Uses. Progress in Lipid Research; 41; 457-500.

Mulyatiningsih, E. (2007). Teknik-teknik Dasar Memasak. Yogyakarta: Universitas Negeri Yogyakarta.

Nagy, B. \& Simándi, B. (2008). Effects of Particle Size Distribution, Moisture Content, and Initial Oil Content on the Supercritical Fluid Extraction of Paprika. Journal of Supercritical Fluids; 46; 293-298.

Nestola, M. \& Schmidt, T. C. (2016). Fully Automated Determination of the Sterol Composition and Total Content in Edible Oils and Fats by Online Liquid Chromatography-Gas ChromatographyFlame Ionization Detector. Journal of Chromatography A; 1463; 136-143.

Normén, L., Johnsson, M., Andersson, H., Gameren, Y. \& Dutta, P. (1999). Plant Sterols in Vegetables and Fruits Commonly Consumed in 
Sweden. European Journal of Nutrition; 38; 8489.

Pangastuti, H. A., Affandi, D. R. \& Ishartani, D. (2013). Karakterisasi Sifat Fisik dan Kimia Tepung Kacang merah (Phaseolus vulgaris L.) dengan Beberapa Perlakuan Pendahuluan. Jurnal Teknosains Pangan; 2; 20-29.

Rahman, M. \& Probosari, E. (2014). Perbedaan Kadar Kolesterol LDL dan HDL Sebelum dan Setelah Pemberian Sari Bengkuang (Pachyrrhizus erosus) pada Wanita. Jurnal of Nutrition College; 3; 587-594.

Rajput, A. P. \& Rajput, T. A. (2012). Isolation of Stigmasterol and $\beta$-sitosterol from Chloroform Extract of Leaves of Corchorus fascicularis Lam. International Journal of Biological Chemistry; 6; 130-135.

Setyaji, D. Y., Prabandari, Y. S. \& Gunawan, I. M. A. (2018). Aktivitas Fisik dengan Jantung Koroner di Indonesia. Jurnal Gizi Klinik Indonesia; 14; 115-121.

Sherma, J. \& Fried, B. (2003). Steroids. In: Handbook of Thin-Layer Chromatography, 3rd edition. New York: Marcel Dekker, Inc.

Sulistyani, M. (2018). Spektroskopi Fourier Transform Infra Red dengan Metode Reflektansi (ATRFTIR) pada Optimasi Pengukuran Spektrum Vibrasi Vitamin C. Jurnal Teknologi dan Manajemen Pengelolaan Laboratorium; 1; 39 43.

Sundari, D., Almasyhuri, A. \& Lamid, A. (2015).
Pengaruh Proses Pemasakan terhadap Komposisi Zat Gizi Bahan Pangan Sumber Protein. Media Penelitian dan Pengembangan Kesehatan; 25; 235-242.

Talreja, T., Kumar, M., Goswami, A., Gahlot, G., Jinger, A. K. \& Sharma, T. (2017). Qualitative and Quantitative Estimation of Phytosterols in Achyranthes aspera and Cissus quadrangularis by HPLC. The Pharma Innovation Journal; 6; 76-79.

Thanh, T. T., Vergnes, M. F., Kaloustian, J., ElMoselhy, T. F., Amiot-Carlin, M. J. \& Portugal, H. (2006). Effect of Storage and Heating on Phytosterol Concentrations in Vegetable Oils Determined by GC/MS. Journal of the Science of Food and Agriculture; 86; 220-225.

Wadhera, R. K., Steen, D. L., Khan, I., Giugliano, R. P. \& Foody, J. M. (2016). A Review of LowDensity Lipoprotein Cholesterol, Treatment Strategies, and Its Impact on Cardiovascular Disease Morbidity and Mortality. Journal of Clinical Lipidology; 10; 472-489.

Wadikar, D., Lakshmi, I. \& Patki, P. (2017). Phytosterols: An Appraisal of Present Scenario. Acta Scientific Nutritional Health; 1; 25-34.

Zhao, H., Zhao, S., Sun, C. \& Guillaume, D. (1989). Glucosylsterols in Extracts of Euryale ferox Identified by High Resolution NMR and Mass Spectrometry. The Journal of Lipid Research; 30; 1633-1637. 